\title{
História psicossocial das emergências humanitárias: Uma sistematização da resposta brasileira ao impacto da COVID-19 na saúde da população
}

Psychosocial history of humanitarian emergencies: A systematization of the Brazilian response to the impact of COVID-19 on the population's health

Historia psicosocial de las emergencias humanitarias: Una sistematización de la respuesta brasileña al impacto del COVID-19 en la salud de la población

\author{
Claudia Henschel de Lima \\ ORCID: https://orcid.org/0000-0002-7693-7321 \\ Universidade Federal Fluminense, Brasil \\ Universidade Federal do Rio de Janeiro, Brasil \\ E-mail: claudialima@id.uff.br
}

\begin{abstract}
Resumo
O objetivo do artigo é apresentar os índices de orientação ideológica do governo brasileiro para o enfrentamento da pandemia de COVID-19, obtidos como resultado do desenvolvimento da pesquisa do Laboratório de Psicopatologia Fundamental em Estudos de Subjetividade e Emergência Humanitária. Nela, foi elaborada a denominação de história psicossocial e clínica das emergências humanitárias para designar o registro sistematizado das pesquisas, informações, ações de governo, estudos de caso, testemunhos, que possibilitem traçar uma história sobre o impacto do contexto de emergências humanitárias - e, mais especificamente, da COVID-19 - na saúde mental das populações. Foram privilegiados os dados obtidos a partir da sistematização: 1.Teórica de referências do pensamento de Sigmund Freud sobre o impacto da emergência humanitária da I Guerra no funcionamento subjetivo; 2.De informações e ações dos países e do governo brasileiro em relação a pandemia de COVID-19, com base na busca de artigos científicos nacionais e internacionais, documentos oficiais da FIOCRUZ, OMS, ONU, IHR e manifestações públicas de autoridades federais em jornais, redes sociais e plataformas de vídeo. Os dados foram coletados, entre 27 de fevereiro de 2020 e 27 de maio de 2021, com base nos seguintes descritores: COVID-19; Emergência humanitária; Políticas de saúde e segurança sanitária; Saúde Mental; Subjetividade; Humanitarian Emergency; Health and health safety policies; Mental health; Subjectivity. Os resultados obtidos foram organizados em quatro eixos: a irrupção da COVID-19; a denominação de emergência humanitária e o impacto da COVID-19 na saúde mental; o aporte financeiro para ciência, tecnologia e inovação no tocante a COVID-19; Ciência e políticas públicas de saúde e segurança sanitária. Eles indicam a elevada orientação ideológica, interferindo na formulação de políticas públicas de saúde para o enfrentamento da pandemia. Os resultados consistiram na formulação de dez índices de orientação ideológica do governo brasileiro para o enfrentamento da pandemia. Eles indicam elevada orientação ideológica, interferindo diretamente na formulação de políticas públicas de saúde e segurança sanitária para sua prevenção e combate.
\end{abstract}

Palavras-chave: História psicossocial; COVID-19; Emergência humanitária; Políticas de saúde e segurança sanitária; Saúde mental.

\begin{abstract}
The objective of the article is to present the Brazilian government's indexes of ideological orientation to face the COVID19 pandemic, obtained as a result of the development of research by the Laboratory of Fundamental Psychopathology in Studies of Subjectivity and Humanitarian Emergency. In it, the term psychosocial and clinical history of humanitarian emergencies was created to designate the systematized record of research, information, government actions, case studies, testimonies, which make it possible to trace a story about the impact of the context of humanitarian emergencies - and, more specifically, COVID-19 - in the mental health of populations. The data obtained from the systematization were privileged: 1. Theoretical references of Sigmund Freud's thought on the impact of the humanitarian emergency of World War I on subjective functioning; 2. Information and actions of countries and the Brazilian government in relation to the COVID-19 pandemic, based on the search for national and international scientific articles, official documents from FIOCRUZ, WHO, UN, IHR and public statements by federal authorities in newspapers, social networks and video platforms. Data were collected between February 27, 2020 and May 27, 2021, based on the following descriptors: COVID19; Humanitarian Emergency; Health and health safety policies; Mental health; Subjectivity; Humanitarian Emergency; Health and health safety policies; Mental health; Subjectivity. The results obtained were organized into four axes: the eruption of COVID-19; the denomination of humanitarian emergency and the impact of COVID-19 on mental health; the financial contribution to science, technology and innovation regarding COVID-19; Science and public health and health
\end{abstract}


security policies. They indicate the high ideological orientation, interfering in the formulation of public health policies to fight the pandemic. The results consisted in the formulation of ten indexes of ideological orientation of the Brazilian government to face the pandemic. They indicate a high ideological orientation, directly interfering in the formulation of public health and health security policies for their prevention and combat.

Keywords: Psychosocial history; COVID-19; Humanitarian emergency; Health and health safety policies; Mental health.

\section{Resumen}

El objetivo del artículo es presentar los índices de orientación ideológica del gobierno brasileño para enfrentar la pandemia COVID-19, obtenidos como resultado del desarrollo de la investigación del Laboratorio de Psicopatología Fundamental en Estudios de Subjetividad y Emergencia Humanitaria. En él, se creó el nombre de historia psicosocial y clínica de emergencias humanitarias para designar el registro sistematizado de investigaciones, información, acciones gubernamentales, estudios de casos, testimonios, que permiten trazar una historia sobre el impacto del contexto de las emergencias humanitarias - y, más específicamente, COVID-19 - en la salud mental de las poblaciones. Se privilegiaron los datos obtenidos de la sistematización: 1. Referencias teóricas del pensamiento de Sigmund Freud sobre el impacto de la emergencia humanitaria de la Primera Guerra Mundial en el funcionamiento subjetivo; 2. Información y acciones de los países y del gobierno brasileño en relación a la pandemia COVID-19, basadas en la búsqueda de artículos científicos nacionales e internacionales, documentos oficiales de FIOCRUZ, OMS, ONU, RSI y declaraciones públicas de autoridades federales en periódicos, redes sociales y plataformas de video. Los datos fueron recolectados entre el 27 de febrero de 2020 y el 27 de mayo de 2021, con base en los siguientes descriptores: COVID-19; Emergencia Humanitaria; Políticas de salud y seguridad sanitaria; Salud mental; Subjetividad; Emergencia Humanitaria; Políticas de salud y seguridad sanitaria; Salud mental; Subjetividad. Los resultados obtenidos se organizaron en cuatro ejes: la erupción del COVID-19; la denominación de emergencia humanitaria y el impacto del COVID-19 en la salud mental; la contribución financiera a la ciencia, tecnología e innovación en relación con COVID-19; Ciencia y salud pública y políticas de seguridad sanitaria. Indican la alta orientación ideológica, interfiriendo en la formulación de políticas de salud pública para combatir la pandemia. Los resultados consistieron en la formulación de diez índices de orientación ideológica del gobierno brasileño para enfrentar la pandemia. Indican una alta orientación ideológica, interfiriendo directamente en la formulación de políticas de salud pública y seguridad sanitaria para su prevención y combate.

Palabras clave: Historia psicosocial; COVID-19; Emergencia humanitaria; Políticas de salud y seguridad sanitaria; Salud mental.

\section{Introdução}

O objetivo do presente artigo é apresentar os primeiros resultados do desenvolvimento da pesquisa que o Laboratório de Psicopatologia Fundamental em Estudos de Subjetividade e Emergência Humanitária, aprovou para o biênio 2020-2022, junto ao Programa de Pós-Graduação em Psicologia da UFRJ e junto ao Departamento de psicologia da UFF- Campus de Volta Redonda.

O desenvolvimento desta pesquisa, no ano de 2020, se deu no contexto de uma relação de cooperação entre o Departamento de Psicologia (UFF. Volta Redonda), o Programa de Pós-Graduação em Psicologia da UFRJ e o Programa de Pós-Graduação em Psicologia da UFPA.

No final de março de 2020, a autora deste artigo foi convidada para integrar como supervisora dos atendimentos clínicos realizados por psicólogos residentes do Hospital Universitário da Universidade Federal do Pará, que atuavam na linha de frente da COVID-19. Esse trabalho de supervisão clínica se articulara formalmente ao projeto de extensão Clínica Psicológica Virtual da Universidade Federal do Pará: Atendimento Psicológico na Pandemia de COVID-19, proposto pelo Programa de Pós-Graduação em Psicologia da Universidade Federal do Pará (PPGP/UFPA). Dessa forma, o contato com uma clínica da saúde mental aplicada à pacientes que sofreram o impacto subjetivo da pandemia de COVID-19 - seja porque foram contaminados e desenvolveram quadros fóbicos relacionados ao medo de morrer, seja porque tiveram familiares que vieram à óbito em um contexto em que houve interrupção dos rituais tradicionais de luto e, por isso, desenvolveram quadros depressivos relacionados a essa interrupção - resultou na elaboração do projeto de extensão Orientação à Profissionais de Psicologia para Atendimento Clínico na Pandemia de COVID19, inscrito e aprovado em 2020, na Plataforma SIGPROJ/MEC, que formalizara a cooperação entre a Universidade Federal Fluminense, a Universidade Federal do Rio de Janeiro e a Universidade Federal do Pará. O trabalho de supervisão clínica permitiu evidenciar a ocorrência de uma série de fenômenos clínicos associados à pandemia de COVID-19 e ao isolamento social, bem como uma fragilização das estratégias psíquicas para lidar com a emergência humanitária e para reconhecer que o isolamento social 
preveniria quanto ao que aconteceu na Italia e na Espanha. A tabela 1 destaca os fenômenos clínicos observados.

Tabela 1. Fenômenos clínicos observados nos pacientes atendidos pela Clínica Virtual do PPGP/UFPA.

\begin{tabular}{|l|}
\hline Insônia. \\
\hline Alteração do apetite (ou comer demasiadamente ou perda do apetite). \\
\hline Medo de se contaminar e de contaminar os entes queridos. \\
\hline Ansiedade. \\
\hline Intensificação de rituais de limpeza. \\
\hline Declínio do sentimento de vida e do interesse por atividades diárias. \\
\hline Dificuldade em manter atividades de rotina. \\
\hline Tristeza. \\
\hline Perda do horizonte de futuro. \\
\hline
\end{tabular}

Fonte: Henschel de Lima (2020-2021).

Esses fenômenos clínicos estão, algumas vezes, acompanhados da intensificação do uso de substâncias psicotrópicas (ansiolíticos e antidepressivos), sugerindo que a fragilização das estratégias para lidar com a situação pandêmica pressiona o funcionamento psíquico na direção de encontrar, por meio da substância psicotrópica, um substituto. A observação desses fenômenos clínicos recolocou, para a pesquisa que já vinha sendo desenvolvida no campo da psicopatologia psicanalítica, a interrogação sobre a especificidade etiológica do recurso à droga, da anorexia e da autolesão à luz da emergência humanitária provocada pela pandemia de COVID-19, a partir de dois novos elementos que podem agravar condições clínicas pré-existentes : o estresse severo provocado pela conjuntura social e econômica e a fragilização das estratégias psíquicas para lidar com a emergência humanitária. Ao longo, então, do ano de 2020, a pesquisa conduziu o registro sistematizado das pesquisas, informações, ações de governo, estudos de caso, testemunhos, focando especificamente no levantamento da literatura sobre emergência humanitária, nas ações de organismos multilaterais, países e do governo brasileiro, em relação a pandemia de COVID-19. O objetivo do artigo é, então expor os índices de orientação ideológica do governo brasileiro para o enfrentamento da pandemia, obtidos como resultado da pesquisa.

\section{Metodologia}

$\mathrm{O}$ artigo apresenta um recorte da pesquisa mais ampla desenvolvida pelo Laboratório de Psicopatologia Fundamental em Estudos de Subjetividade e Emergência Humanitária. Trata-se de um estudo exploratório e descritivo, com análise sobre emergência humanitária, sobre a especificidade da pandemia de COVID-19 e seu impacto sobre a saúde mental de populações a partir do marco teórico da psicanálise freudiana. O conjunto de informações sobre o impacto da pandemia de COVID-19 e da quarentena sobre o funcionamento psíquico se dá sobre o acúmulo do conhecimento que está sendo produzido, no contexto da pandemia de COVID-19, em torno do que a autora deste artigo define por meio da denominação história psicossocial e clínica das emergências humanitárias. Essa denominação, define o registro sistematizado das pesquisas, informações, ações de governo, estudos de caso, testemunhos, que possibilitem traçar uma história sobre o impacto do contexto de emergências humanitárias - e, mais especificamente, da COVID-19 - na saúde mental das populações (Henschel de Lima, 2020). Para o presente artigo teórico, foram privilegiados os dados obtidos a partir da da sistematização:

1.Teórica de referências do pensamento de Sigmund Freud sobre o impacto da emergência humanitária da I Guerra no funcionamento subjetivo.

2.De informações e ações dos países e do governo brasileiro em relação a pandemia de COVID-19, com base no levantamento de: 
I. Artigos científicos nacionais e internacionais: o levantamento foi realizado por meio da busca de artigos indexados na Biblioteca Virtual em Saúde (BVS), e Scientific Electronic Library Online (SciELO), com o auxílio das seguintes bases de dados: PubMed (National Center for Biotechnology Information) e Lilacs (Literatura Latino-Americana e do Caribe em Ciências da Saúde).

II. Documentos oficiais da FIOCRUZ, OMS, ONU, IHR.

III. Manifestações públicas de autoridades federais em jornais, redes sociais e plataformas de vídeo.

Os dados dos levantamentos foram coletados, entre 27 de fevereiro de 2020 e 27 de maio de 2021, com base nas seguintes palavras-chaves: COVID-19; Emergência humanitária; Políticas de saúde e segurança sanitária; Saúde Mental; Subjetividade; Humanitarian Emergency; Health and health safety policies; Mental health; Subjectivity.

\section{Resultados e Discussão}

Os resultados obtidos foram organizados em quatro eixos:

1.A irrupção da COVID-19.

2. A denominação de emergência humanitária e o impacto da COVID-19 na saúde mental.

3.O aporte financeiro para ciência, tecnologia e inovação no tocante a COVID-19.

4.Ciência e políticas públicas de saúde e segurança sanitária.

\subsection{COVID-19}

Sobre a irrupção da COVID-19, os documentos da Organização Mundial de Saúde (OMS), datam a irrupção do novo coronavírus (COVID-19) em dezembro de 2019. Provocada pelo vírus SARS-COv-2, primeiramente, fora localizada como uma epidemia regional localizada na província de Wuhan, na China, e comunicada pela primeira vez aos membros da OMS em 31 de dezembro de 2019.

Em 30 de janeiro de 2020, a OMS declara o surto da COVID-19, como uma emergência de saúde pública de magnitude e importância internacional - o mais alto nível de alerta da OMS. Em 9 de março de 2020, o governo italiano anuncia medidas emergenciais severas de contenção do vírus; em 11 de março de 2020, a OMS decreta como pandêmica a COVID-19. Desde então, o mundo fora atravessado por uma nova emergência em saúde pública, com o mais alto risco de contaminação de todo o mundo.

Da Ásia à Europa, à África e à América do Norte e América Latina, foram apenas três meses, sucumbindo o mundo em uma emergência humanitária veloz, dado o grau de contaminação do vírus e, em alguns casos, dado o grau de severidade podendo levar a óbito. A contaminação ocorre por meio do contato com aerossóis, podendo ainda ocorrer por meio do contato com superfícies contaminadas. Ressalta-se o grau elevado de sua taxa de transmissão: cada 1 pessoa infectada, infecta 3 pessoas, produzindo a sobrecarga dos sistemas de saúde até seu colapso no mundo todo. Com relação ao registro do avanço da contaminação e do número de óbitos, especificamente no Brasil, mesmo considerando a subnotificação, os dados oficiais registram, desde a decretação da pandemia pela OMS, a manutenção do elevado número de casos. Vale acrescentar que desde junho de 2020, após decisão do governo brasileiro de restringir o acesso a dados informativos sobre a evolução da pandemia de COVID-19 - mais precisamente, ao número de infectados e de óbitos no Brasil - a publicização das informações passou a ser responsabilidade do consórcio de imprensa, formado pelos jornais G1, O Globo, Extra, Estadão, Folha e UOL. Este consórcio coleta, diariamente, junto as Secretarias Estaduais e Municipais de Saúde, os dados sobre contaminação e óbito por COVID no país (G1, O Globo, Extra, Estadão, Folha e UOL, 2020).

A notícia mais recente, publicada em 16 de junho de 2021 pelo consórcio de imprensa, registra que, neste momento, o Brasil supera o número total de 17 milhões de infectados sendo o segundo país do mundo em números absolutos de óbitos no país. 
Assim, a COVID-19 impõe que governos do mundo todo desenvolvam, com urgência, políticas públicas de saúde e segurança sanitária a fim de reduzir sua taxa de contaminação e os óbitos, bem como os efeitos de longo prazo sobre a saúde física e mental da população.

Um horizonte de solução da pandemia de COVID-19 no mundo, por meio de medicamentos antivirais e desenvolvimento de vacinas que impeçam a infecção viral, ainda está distante. Mas, se de um lado, hoje, o mundo ainda se encontra neste ponto no campo da saúde física, de outro, há uma experiência histórica sobre o impacto de emergências humanitárias na saúde mental de indivíduos, família e sociedade.

Em Reflexões sobre os Tempos de Guerra e Morte (1915/1987), o fundador da psicanálise Sigmund Freud, conduz uma reflexão crítica sobre o impacto da I Guerra no funcionamento subjetivo. Do trecho reproduzido abaixo, é possível depreender impactos importantes: "É compreensível que o cidadão do mundo civilizado a quem me referi possa permanecer desamparado num mundo que se lhe tornou estranho - sua grande pátria desintegrada, suas propriedades comuns devastadas, seus concidadãos

divididos e vilipendiados". (Freud, (1915/1987, p. 316). Esse trecho destaca, após um ano de irrupção da I Guerra, os seguintes impactos observados por Freud (1915/1987):

1.Desamparo.

2.Sentimento de desintegração social.

3.Divisão.

4.Desapontamento.

São impactos subjetivos muito graves, que não podem ser desprezados como variaveis estranhas à pesquisa científica e foram fundamentais no reconheciento dos fenômenos clínicos extraídos dos casos clínicos atendidos pelos profissionais de psicologia que compõem a clínica virtual de atendimento psicológico do PPGP/UFPA. A ocorrência desses impactos revela, ainda, a necessidade de que as medidas de saúde pública para prevenção da propagação do SARS-COV-2 (desde a higiene das mãos até o distanciamento social e as medidas de lockdown) exige sua articulação com a investigação científica dos mecanismos psicológicos subjacentes a diferentes reações ao desencadeamento da COVID-19 no mundo (desde a reação psicológica de medo de contaminar e ser contaminado até o negacionismo relacionado ao reconhecimento da pandemia e de sua gravidade). $\mathrm{O}$ editorial de 23 de março de 2020, da London School of Economics and Political Science, intitulado Social Science in Time of Social Distancing, afirma a indissociabilidade entre os campos da pesquisa científica em saúde pública e em ciências humanas:

En esta pandemia que lleva aparejada una oleada de bulos y desinformación, los psicólogos explican los mecanismos que están detrás de estas acciones y cómo nuestro cerebro está influido por los sesgos y por el miedo, lo que puede provocar que bajemos la guardia ante bulos o que procesemos mal los contenidos verídicos.

A sistematização das referências, exposta nesta seção do artigo, se coaduna com as referências da literatura científica recente sobre a correlação entre a eclosão de formas de sofrimento psíquico e a ocorrência de acontecimentos sociais com forte impacto traumático, especialmente no tocante ao funcionamento do eu, à regulação do afeto e às relações intersubjetivas (Briere \& Spinazzola, 2005, Schmid et al., 2013, Cloitre et al, 2014), sendo também consistentes com os achados da Organização Mundial da Saúde (2020) e da Fiocruz (2020), que serão apresentados na próxima seção, como impactos de emergências humanitárias.

\subsection{Denominação de emergência humanitária e impacto na saúde mental}

Guerras, conflitos sociais, golpes de estado, doenças infectocontagiosas, desastres naturais, compõem o que a Organização Mundial da Saúde (OMS) definira como sendo o quadro das emergências humanitárias. Emergências humanitárias impõem condições muito duras às populações evidenciando o limite de nossa capacidade de sobrevivência, colocando para nós a condição 
da finitude ou o que Freud denominara de desamparo fundamental (hilflosikheit). Sabemos, pelos registros históricos da I Guerra, a relevância que esse tema tomou no pensamento de Freud. Um testemunho particularmente importante é o de Freud, em momentos precisos de sua reflexão sobre a I Guerra.

O primeiro momento antecede, em cerca de um ano, a I Guerra. Trata-se do encontro entre Freud, Rainer Maria Rilke e Lou Andreas Salomé, em agosto de 1913 e girou em torno desta condião de finitude e do sentimento de desamparo fundamental. Durante todo o tempo, Rilke admirava a beleza da natureza ao redor, sem extrair nenhuma fruição disso. O encontro foi tema de Transitoriedade (1916/2020), escrito para uma obra sobre Goethe, organizada pela Sociedade Goethe de Berlim. No texto, Freud interroga sobre os processos psíquicos que estariam na base da experiência de transitoriedade. Freud relata que Rilke estava taciturno, atravessado por um profundo sentimento de que a beleza é efêmera pois desaparece com a chegada do inverno. Esse sentimento logo se estende à vida. Ela é efêmera e está condenada ao desaparecimento: "Perturbava-o a ideia de que no inverno ela desapareceria dali, assim como toda beleza humana e tudo o que é belo e nobre que o homem criou e poderia criar" (Freud, 1916/ 2020, p. 221).

É possível reconhecer nos sentimentos do poeta, a tonalidade do sentimento de perda, de luto e de melancolia, diretamente bordado em Considerações Contemporâneas sobre a Guerra e a Morte (1915/2020) e em Luto e Melancolia (1917/2020, p.223224), em que identificara o quão profunda fora a dimensão de perda sofrida com a I Guerra:

Ela não destruiu apenas a beleza das paisagens que atravessou e as obras de arte que encontrou em seu caminho, ela atingiu também nosso orgulho pelas qualidades de nossa cultura, nosso respeito por tantos poetas e artistas, nossa esperança, enfim, por uma superação das diferenças entre povos e raças. Ela sujou a sublime neutralidade de nossa ciência, deixou nua nossa vida pulsional, desacorrentou nossos maus espíritos, que acreditávamos permanentemente domados por décadas de educação por parte de nobres predecessores. Ela tornou nossa pátria novamente pequena e outras terras distantes vastas. Ela roubou muito de nós, o que amávamos, e nos mostrou a caducidade de muitas coisas que acreditávamos estáveis. (Freud, 1915/2020, p.223-224).

A fineza da análise de Freud acerca do impacto da Guerra sobre a subjetividade foi notável, em ambos os textos. Em Luto e Melancolia (1917/2020) ele ressalta, no quadro da reflexão sobre o destino da libido a partir da perda do objeto amado, o impacto que um acontecimento histórico como a Guerra pode ter a forma como o ser humano se relaciona afetivamente, pathicamente, com a realidade simbólica. Aqui, ele estabelece uma distinção entre o estado de ânimo do luto e da melancolia. Ambos possuem as mesmas características, com exceção do rebaixamento da autoestima. Assim, se ambos se caracterizam pela irrupção de um sentimento de desânimo profundo e doloroso, pela suspensão do interesse pela vida, com perda da capacidade de amar, inibição da atividade, a melancolia traz a especificidade do rebaixamento da autoestima:

A melancolia se caracteriza psiquicamente por um desânimo profundamente doloroso, por uma suspensão do interesse pelo mundo externo, pela perda da capacidade de amar, pela inibição da capacidade para a realização e pelo rebaixamento da autoestima, que se expressa em autorrecriminações e autoinsultos, até atingir a expectativa delirante de punição. (Freud, 1917/2020, p. 100).

No luto, o sujeito perde o interesse por tudo o que não se refere ao objeto de amor perdido, tudo o que não esteja ligado à sua lembrança. Isso se deve pelo fato de que a prova de realidade indica que o objeto amado não mais existe, impondo uma retirada do investimento pulsional de sua ligação com o objeto. Dessa forma, o processo de luto é o processo de desligamento em relação ao objeto perdido com investimento na lembrança inconsciente e idealizada deste objeto até sua finalização com o reinvestimento em novos objetos libidinais. Na melancolia, ocorre que o sujeito sabe exatamente quem ele perdeu porque a perda ocorre no eu, mas não houve o trabalho inconsciente de investimento na lembrança do objeto perdido. Isso indica um estado de ânimo diferente do luto, pois evidencia que algo no campo do funcionamento inconsciente não ocorreu. No lugar do processo de retraimento no 
investimento no objeto perdido na direção de sua lembrança e idealização, a melancolia revela uma perda sofrida no eu, com retraimento do investimento pulsional no objeto perdido sem investimento na lembrança inconsciente. É o que Freud (1917/2020) caracterizara como identificação narcísica (o eu é o objeto perdido) e hemorragia pulsional: há o retraimento do investimento pulsional diretamente sobre o eu, sem o anteparo da lembrança idealizada do objeto perdido no inconsciente. O rebaixamento da autoestima na melancolia se deve à hemorragia pulsional:

O melancólico ainda nos mostra algo que falta no luto: um extraordinário rebaixamento da autoestima do Eu, um grandioso empobrecimento do Eu. No luto, o mundo se tornou pobre e vazio; na melancolia, foi o próprio Eu. O doente nos descreve seu Eu como indigno, incapaz e moralmente desprezível; ele se recrimina, insulta-se e espera ser rejeitado e castigado. Ele se humilha diante de qualquer pessoa e sente pesar por seus familiares estarem ligados a uma pessoa tão indigna. Ele não julga que uma mudança lhe aconteceu, mas estende sua autocrítica ao passado; ele afirma que nunca foi melhor. (Freud, 1917/2020, p. 102-103).

Com essa descrição, Freud não só define a distinção entre os estados de ânimo que um ser humano assume diante da perda do objeto amado - que pode ser um ente querido, uma abstração do tipo pátria, liberdade, ideal - como também localiza, na melancolia, um estado de ânimo específico em que se observa a retração do investimento da pulsão sobre o eu. Esse ponto parece percorrer as entrelinhas de Linhas de Progresso da Técnica Psicanalítica (1918/1987). É uma conferência apresentada no V Congresso Psicanalítico Internacional, em Budapeste, em que Freud movimenta sua reflexão para a contabilização de traumatizados e mortos no front, alertando para a miséria do mundo que se aprofundava para a humanidade com o aumento dos casos de angústia e desamparo. E na contramão de qualquer otimismo ilusório quanto ao futuro, Freud (1918/1987) previu a equivalência epidêmica do sentimento de desamparo e angústia à própria tuberculose como consequências diretas do impacto da I Guerra sobre o funcionamento subjetivo. O que levanta a interrogação a respeito dos estados de ânimo diante da perda do objeto, feita por ele tanto em Transitoriedade (1915/2020) como em Luto e Melancolia (1917/2020), escritos no contexto da I Guerra. E nos conduz a pensar que a equivalência epidêmica entre miséria subjetiva e tuberculose responde à algo que se concretizará em Psicologia das massas e Análise do Eu (1921/2020): o grau de destruição de uma emergência humanitária (sobre os bens preciosos comuns à uma cultura, sobre orgulho pelas qualidades de nossa cultura, nosso respeito por tantos poetas e artistas, nossa esperança pela superação das diferenças entre povos e raças), pode impactar profundamente o funcionamento inconsciente, desnudando nossa vida pulsional, desacorrentando nossos maus espíritos, que podem se voltar agressivamente contra o eu. Freud não se equivocou.

Poucos mais de cem anos se passaram e o discurso do secretário-geral da Organização das Nações Unidas (ONU), António Guterrez, para o lançamento do relatório COVID-19 and the Need for Action on Mental Health, em 13 de maio de 2020 não se separa da previsão de Freud ao deixar claro que, apesar da pandemia de COVID-19 ser uma crise de saúde física, ela produz uma ampla crise de saúde mental com potencial de agravamento da miséria do mundo:

(...) luto pela perda de entes queridos, choque com a perda de empregos, isolamento e restrições à circulação, dinâmicas familiares difíceis, incerteza e medo do futuro. Problemas de saúde mental, incluindo depressão e ansiedade, são algumas das maiores causas de miséria no nosso mundo. (...) Após décadas de negligência e de investimento insuficiente em serviços de saúde mental, a pandemia de COVID-19 está a atingir famílias e comunidades com um stress mental adicional. (...) Mesmo quando a pandemia estiver sob controle, a dor, a ansiedade e a depressão continuarão a afetar as pessoas e as comunidades. (...). Os serviços de saúde mental são uma parte essencial de todas as respostas do governo à COVID-19. (...) Apelo aos governos, à sociedade civil, às autoridades de saúde, e a outros, que reúnam com urgência para abordar a dimensão da saúde mental desta pandemia. (Guterrez, 2020).

No caso específico de epidemias/pandemias, os últimos quarenta anos, testemunhou como a humanidade viveu sob a pressão de epidemias/pandemias virais com forte impacto sobre a saúde mental de indivíduos e comunidades. A tabela 2, elaborada para a pesquisa, apresenta sinteticamente um traçado histórico das epidemias que irromperam no mundo a partir da década de 1980. 
Tabela 2. Breve histórico de epidemias/pandemias a partir da década de 1970 no mundo e no Brasil.

\begin{tabular}{|c|c|}
\hline Epidemias/ Pandemias & Ano \\
\hline Meningite & 1974 \\
\hline HIV/AIDS & $1980-1990$ \\
\hline SARS & $2002-2003$ \\
\hline H1N1 (Influenza) & 2009 \\
\hline MERS & 2012 \\
\hline Ebola & 2013 \\
\hline Zika & 2016 \\
\hline COVID-19 & 2020 \\
\hline
\end{tabular}

Fonte: Henschel de Lima (2020).

Os cientistas mostram como o rastreio histórico das estratégias de enfrentamento em epidemias passadas, é fundamental para acumular estratégias de enfrentamento da emergência humanitária de COVID-19. A tabela 1 evidencia que a irrupção da COVID-19 não deveria causar surpresa entre as autoridades de uma país. Apesar da tabela estabelecer um corte a partir do ano de 1974, desde a gripe espanhola, já se conhece o coronavírus, e se registrou desde a década de 1940 o aumento da irrupção de doenças infecciosas no mundo (Nuzzo, 2021).

No caso específico de vírus respiratórios, eles têm o potencial de causar graves doenças e altas taxas de mortalidade na maior parte dos casos registrados no mundo. A SARS, que eclodiu no mundo nos anos de 2002-2003, produziu uma taxa de mortalidade de 10\% das pessoas que contraíram a doença e a MERS, em 2012, teve uma taxa de mortalidade da doença em 35\% das pessoas infectadas. O mesmo ocorreu com a H1N1(conhecida como "gripe suína") que, em um ano, registrou entre 151,7 mil e 575,4 mil mortes, sendo que cerca de $80 \%$ dos óbitos ocorreram na população mais jovem.

O documento Social Science in Epidemics: Influenza and SARS. Lessons Learned (Ripoll; Wilkinson, 2019), apresenta quinze lições importantes extraídas das epidemias de SARS e H1N1. A Tabela 3 apresenta sinteticamente o enunciado dessas lições.

Tabela 3. As quinze lições aprendidas com a SARS e H1N1 para o enfrentamento da COVID-19.

1. Os vírus da pandemia De H1N1 e da SARS têm maior probabilidade de surgir e se espalhar em ambientes com aglomeração de animais (aves e suínos) e / ou humanos.

2. O tamanho da fazenda e a intensidade da produção de porcos e aves determinam o risco de H1N1; as medidas de controle podem ter impactos desproporcionais em fazendas de menor risco.

3. Os sistemas de vigilância podem ser fortalecidos com a inclusão de profissionais de saúde não biomédicos e insumos não relacionados à saúde.

4. Os sistemas de vigilância devem incorporar o fato de que a H1N1 e a SARS envolvem um conjunto de sintomas que podem ser mencionados em diferentes termos e categorias, dependendo das origens culturais.

5. A velocidade de transmissão irá variar por cepa, e isso pode contrastar com ideias locais de transmissão e risco.

6. A vulnerabilidade à infecção e mortalidade por H1N1 é moldada por fatores biológicos e sócio-demográficos.

7. As mensagens de prevenção de riscos devem ser baseadas em valores compartilhados e entregues por intermediários confiáveis.

8. Relações históricas e políticas podem indicar que grupos específicos correm o risco de estigmatização em uma pandemia de H1N1.

9. Reter informações do público é potencialmente muito prejudicial.

10. As abordagens que valorizam ações voluntárias são preferíveis às abordagens coercitivas, ao buscar conformidade com as restrições de movimento, quarentena e distanciamento social.

11. As pessoas podem buscar tratamento para H1N1 ou SARS de sistemas de saúde alternativos.

12. Os sistemas de triagem, hospitalização e alocação de recursos, precisam ser transparentes.

13. As experiências dos profissionais de saúde precisam ser consideradas com cuidado.

14. Preparar provedores mortuários e funerários para mortalidade em massa e garantir que as práticas funerárias reconciliem as preocupações de saúde pública com as necessidades sociais e emocionais das comunidades

15. As atitudes em relação à segurança e eficácia da vacina variam e como a vacinação é implementada, em uma pandemia, pode aumentar a desconfiança. 
Fonte: Ripoll; Wilkinson (2019).

A leitura das lições deixa evidente a necessidade de inclusão de cuidados psicológicos relacionados a perdas humanas e a transmissão da informação sobre a infecção viral, sobre a gravidade da infecção e sobre as formas de prevenção e acesso à vacinas. Isso significa que uma emergência humanitária, seja ela uma guerra ou uma pandemia, afeta diretamente a saúde mental das populações. Hoje, os documentos da OMS acumulam informações sobre o impacto de emergências humanitárias sobre a saúde mental, conforme se depreende do Guia de Intervenção Humanitária (GIH-mhGAP): Manejo Clínico de Condições Mentais, Neurológicas e por Uso de Substâncias em Emergências Humanitárias (OPAS, 2020):

1.O agravamento de sofrimentos psíquicos preexistentes - como é o caso do transtorno depressivo moderado a grave, da psicose e do uso prejudicial de álcool e outras drogas.

2.O desencadeamento de outras formas de sofrimento, diretamente decorrentes da exposição humana às condições de emergência humanitária, como é o caso do estresse agudo, luto e do transtorno de estresse pós-traumático.

O guia é, ainda, preciso no ponto em que alerta para o fato de que o conjunto de formas de sofrimento psíquico preexistentes, e agravadas por situações humanitárias emergenciais, ou desencadeadas por elas, apresentam risco de autolesão e suicídio. Neste sentido, a própria OMS (2020) vem estabelecendo orientações à população mundial no sentido de reduzir a ansiedade deste período, recomendando ainda o evitamento de determinadas estratégias de coping ou enfrentamento, para lidar com as situações de saúde mental - como é o caso do uso de substâncias psicoativas. Eles também corroboram o próprio quadro sintomático já identificado no primeiro trimestre de uma emergência humanitária tal como é apresentado pelo documento da Fiocruz (2020) Saúde mental e Atenção psicossocial na Pandemia COVID-19: Recomendações Gerais. O documento prevê a ocorrência de reações similares na pandemia de COVID-19, considerando a data de início do primeiro trimestre em cada região, conforme exposto na Tabela 4:

Tabela 4. Quadro sintomático identificado no primeiro trimestre da emergência humanitária de COVID-19.

Medo: de adoecer e de morrer pela doença; de infectar outras pessoas; de perder entes queridos; de perder os meios de subsistência e a renda; de ser excluído socialmente ou por ter a doença ou por ser um profissional da linha de frente.

ensações de: incerteza quanto ao futuro, impotência frente aos acontecimentos, desamparo, solidão, tristeza, luto e ansiedade.

Iterações comportamentais: alimentares (ter mais apetite ou menos apetite), no sono (insônia ou sono em excesso, pesadelos).

gravamento de conflitos interpessoais com familiares, no trabalho.

lterações no pensamento: pensamentos recorrentes sobre a pandemia, a saúde dos entes queridos, a morte e o morrer.

Fonte: Adaptado de FIOCRUZ (2020).

A Tabela 4 indica como o contexto de emergência humanitária é uma condição de estresse severa e adicional às populações, impactando diretamente no bem-estar psicossocial. No entanto, o conjunto de registros acumulados sobre esse impacto, não impediu que a área de saúde mental fosse das mais negligenciadas pelos governos.

O relatório da OPAS, A carga dos transtornos mentais na região das Américas (2018), já mostrara - dois anos antes do desencadeamento da pandemia de COVID-19 - que na América Latina, Caribe não latino, América do Sul, Canadá e Estados Unidos, problemas de saúde mental são responsáveis por mais de 1/3 do número total de incapacidades. E, no entanto, o relatório registra como o financiamento em saúde mental estava abaixo do necessário, não respondendo à cobertura das necessidades na área. Até 2018, o déficit variava de 3 vezes a mais que os gastos atuais em países das Américas de alta renda a 435 vezes os gastos nos países de mais baixa renda da região (OPAS, 2018). O que explica a preocupação da ONU em conscientizar os países para reverter a negligência e o baixo investimento em serviços de saúde mental em prol da ampliação da cobertura psicossocial para indivíduos, famílias e comunidades que foram afetadas pelos impactos da incerteza quanto ao desenvolvimento de medicamentos e vacina para 
a COVID-19, da incerteza quanto ao futuro, do isolamento e das perdas de entes queridos que não puderam ser elaboradas por meio do ritual coletivo do luto e do funeral.

O estudo de Lai et al (2020) registra na República da China, altas taxas de ocorrência de depressão (50\%), ansiedade (45\%) e insônia (34\%) em profissionais da saúde. E isso também se verifica na população em geral. A ONU (2020) cita dois estudos recentes na Etiópia e no Canadá. Os dados de Ambaw et al (2020), referentes a população do estado de Amhara, na Etiópia, estimaram um percentual de 33\% de sintomas consistentes para transtorno depressivo no contexto da pandemia de COVID-19, representando um aumento de 3 vezes em comparação com as estimativas da Etiópia antes da pandemia. Essas estimativas ganham uma gravidade adicional quando se verifica que, para lidar com o fator estressor da pandemia, os indivíduos recorrem ao uso de substâncias psicoativas, ou desenvolvem comportamentos aditivos relacionados a internet. A estatística do Canadá, sobre consumo de álcool, evidencia que $20 \%$ da população entre 15 e 49 anos aumentou o consumo durante a pandemia de COVID-19.

O estudo de Thackur et al (2020) é, particularmente significativo e merece destaque por apresentar uma amostra de referências de estudos de caso, no ano de onde se destacam o impacto do isolamento social, da crise econômica e do estresse e ansiedade vividos por profissionais de saúde como fatores preditores para o desencadeamento de depressão e suicídio no contexto da pandemia de COVID-19. A tabela 5 reproduz esses achados de Thackur et al (2020).

Tabela 5. Casos representativos de condições psicológicas e fatores preditores subjacentes para suicídio no quadro da COVID-19.

\begin{tabular}{|c|c|}
\hline Casos & Fatores Preditores \\
\hline I.Isolamento Social/distanciamento: & \\
\hline $\begin{array}{l}\text { 1.Santosh Kaur, uma mulher de } 65 \text { anos, cometeu } \\
\text { suicídio por medo da COVID-19. (India) }\end{array}$ & $\begin{array}{l}\text { A pessoa estava deprimida, ansiosa por causa da COVID-19 e estava sozinha. Estava } \\
\text { sem suporte ou apoio. }\end{array}$ \\
\hline $\begin{array}{l}\text { 2.Estudante chinês vivendo na Arabia Saudita } \\
\text { cometeu suicídio pulando do terceiro andar de um } \\
\text { hospital. (Arabia Saudita) }\end{array}$ & Quarentenado por suspeita de infecção por COVID-19. \\
\hline $\begin{array}{l}\text { 3.Emily Owen, } 19 \text { anos, vítima de suicídio } \\
\text { (Inglaterra) }\end{array}$ & Medo do isolamento desencadeado pelo anúncio de lockdown no país. \\
\hline $\begin{array}{l}\text { II. Lockdown gerando recessão econômica: } \\
\text { Ministro de finanças Thomas Schaefer, de } 54 \text { anos. } \\
\text { (Alemanha) }\end{array}$ & $\begin{array}{l}\text { Não estava em condições de lidar com o estresse oriundo da crise econômica da } \\
\text { COVID-19. Desesperançado quanto ao fato de que seria capaz de administrar as } \\
\text { expectativas da população com relação a ajuda financeira. }\end{array}$ \\
\hline $\begin{array}{l}\text { III. Estresse, ansiedade pressão sobre profissionais } \\
\text { da saúde: }\end{array}$ & \\
\hline $\begin{array}{l}\text { 1.Enfermeira de } 49 \text { anos, do Jesolo Hospital, } \\
\text { cometeu suicídio pulando no rio Piave (Itália) }\end{array}$ & Vivia sozinha e estressada \\
\hline $\begin{array}{l}\text { 2. Daniela Trezzi, Enfermeira de } 34 \text { anos, do } \\
\text { Hospital San Gerardo (Itália) }\end{array}$ & $\begin{array}{l}\text { Profundamente traumatizada, exausta, burnout emocional, desesperançada e com medo } \\
\text { de contrair a doença e contaminar pessoas. }\end{array}$ \\
\hline $\begin{array}{l}\text { IV.Boicote e discriminação social: } \\
\text { 1.Mustaffa, de } 35 \text { anos, } \\
\text { e Mohammad Dilshad, de } 37 \text { anos, cometeram } \\
\text { suicídio. (India) }\end{array}$ & $\begin{array}{l}\text { Ambos sofriam boicote e discriminação social e religiosa por parte de seus vizinhos, } \\
\text { que suspeitavam que eram positivo para COVID-19. O resultado foi o isolamento, o } \\
\text { estigma e a depressão. }\end{array}$ \\
\hline
\end{tabular}

Fonte: Adaptado de Thackur et al (2020).

Thackur et al (2020) destacam o impacto do isolamento social, da crise econômica, da discriminação social e do estresse e ansiedade vividos por profissionais de saúde como fatores preditores para o desencadeamento de depressão e suicídio no contexto 
da pandemia de COVID-19. Hoje, mesmo após um ano do surto em Wuhan, não há literatura científica vasta sobre a amplitude precisa desse impacto sobre a saúde mental.

No contexto de uma pandemia da magnitude da COVID-19 - em que medidas de saúde pública como a obrigatoriedade do uso de máscaras, higiene de mãos, isolamento social com medidas restritivas de eventos de aglomeração e, mais radicalmente o lockdown, foram as principais direções de prevenção da infecção viral, e que a incerteza quanto ao futuro se consolidou como horizonte em um cenário, ainda sem medicamentos e com escassez de produção de vacinas - é crucial que a governança da pandemia passe pelo:

1.Aporte de recursos financeiros para o desenvolvimento da pesquisa científica em todas as áreas do conhecimento.

2.Publicização em linguagem clara das lições acumuladas em emergências humanitárias anteriores.

No caso específico do Brasil, o aporte financeiro para a pesquisa científica parece retroceder na exata proporção em que avança a ideia de que a pandemia de COVID-19 não é uma pandemia.

\subsection{A Governança da Pandemia e a situação do Brasil}

Surtos de doenças infecciosas, pelo mundo, são impreditíveis. No entanto, desde o ano de 1969, a OMS adota o International Health Regulations (IHR) - um conjunto de linhas diretrizes que define direitos e obrigações dos países para lidar com eventos de saúde pública e emergências que têm o potencial de cruzar as fronteiras e concede ao diretor geral da OMS, o poder de declarar uma emergência de saúde pública de magnitude e importância internacional. Há debates em torno da possível hesitação da OMS em declarar quando um surto de doença viral e/ou infecto-contagiosa é pandêmico.

Nuzzo (2021) destaca que, durante a epidemia de Ebola no oeste da Africa, a OMS levara mais de quatro meses desde o início do surto, para declará-la como epidemia. O mesmo acontecera com o surto da doença no Congo, em 2018: foram 11 meses até a declaração da epidemia. Conforme, foi abordado na seção 2 do presente artigo, no caso da COVID-19, o surto em Wuhan aconteceu em dezembro de 2019, e na reunião de 22 e 23 de janeiro de 2020, a OMS ainda declinara na declaração de emergência humanitária, só o fazendo uma semana depois. Isso não significa que a OMS não reconheça esse ponto. Tedros Adhanom avaliara, em agosto de 2020, que a COVID-19 era um teste ácido para a IHR, anunciando que um comitê independente iria avaliá-las. De fato, a última grande revisão ocorreu após uma década de debate e foi concluída apenas em resposta ao choque da SARS. Ainda assim, desde o ano de 2007 a OMS por meio do documento Risk reduction and emergency preparedness: WHO six-year strategy for the health sector andcommunity capacity development (2007), vem alertando para a necessidade de uma política global de prevenção, mitigação e preparação para situações de emergência, desastres e outras crises, utilizando a experiência passada de situações similares. No documento, a OMS (2007) deixa bem claro o quanto esse quadro impacta primordialmente a saúde da população afetada, tanto no que se refere aos impactos diretos que uma pandemia, ou uma situação de guerra e conflito, produzem na estrutura física dos sistemas de saúde. Danos à estrutura física, sobrecarga de hospitais, a escassez de insumos farmacêuticos e hospitalares, são comuns em cenários de doenças, riscos de morte e comprometimentos psicológicos de longo prazo. Diante deste cenário verificado pela experiência histórica com emergências e crises, a OMS (2007) propôs uma estratégia de redução do risco e preparação para emergências com base na similaridade entre as diversas situações de emergência e na unidade da resposta a fim prevenir a sobrecarga de serviços de saúde e garantir que vidas sejam salvas e o sofrimento físico e mental seja reduzido.

No caso específico do Brasil, ficou manifesto o alinhamento do governo às decisões do governo de Donald Trump, nos Estados Unidos - em especial, no que se refere a OMS e suas diretrizes para lidar com a pandemia de COVID-19. Esse alinhamento se verifica na forma como o Presidente da República desrespeitou as recomendações de epidemiologistas, infectologistas, que conduzem pesquisas cientificas nas Universidades e fundações de pesquisa (Butantan e FIOCRUZ) quanto às orientações para prevenção contaminação e contágio (uso de máscaras, higienização de mãos, medidas de restrição e isolamento social) e quanto ao 
uso indiscriminado de hidroxicloroquina como suposta terapêutica medicamentosa para a COVID-19. Além de direcionar fortes críticas à Fundação Butantan, que sintetizou a vacina CORONAVAC, em parceria com a China. Durante todo o ano de 2020, a vacina sintetizada pelo Butantan era qualificada como vacina chinesa sem comprovação científica quanto a sua eficácia.

No que se refere ao controle de passageiros oriundos de vôos internacionais, recomendado pelo IHR, não houve observância quanto a esse ponto, a despeito do fato de estudos científicos conduzirem rastreamentos do vírus no país e indicarem a necessidade de segurança sanitária nos aeroprotos brasileiros. Por exemplo, o estudo de Candido et al (2020), sobre a evolução e a propagação epidêmica do SARS-COV-2 no Brasil, trabalha com duas hipóteses para o rastreamento do vírus no país: os estados de São Paulo - onde foi registrado o primeiro caso em 26 de fevereiro de 2020 - e Rio de Janeiro teriam suas contaminações explicadas por vôos oriundos da Itália espalhando-se para outros estados brasileiros; no caso da Amazônia, por causa da Zona Franca de Manaus, o vírus pode ter entrado na Amazônia por meio de vôos diretos da China.

Desde a primeira contaminação em São Paulo, a COVID-19 descortinou a profunda crise política no país com tensões internas graves, promovidas pelo choque entre a concepção ideológica da presidência da república em relação a COVID-19, exposta em declarações do Presidente e as orientações do Ministério da Saúde nos três primeiros meses da pandemia, dos governos estaduais e prefeituras, que procuravam seguir as diretrizes da OMS para o enfrentamento da pandemia.

Os dados publicados no estudo Mapeamento e Análise das Normas Jurídicas de Resposta à COVID-19 no Brasil (CEPEDISA, 2021), indicam uma resposta afirmativa à pergunta aqui colocada. Foram encontradas 3.049 normas relacionadas à COVID-19, editadas pelo Poder Executivo, entre 01 de janeiro de 2020 e 28 de maio de 2021. Esse número de normas vem acompanhado por vários problemas. Destaca-se, aqui, impasses na conformidade dos atos normativos do poder executivo com a lei e com a Constituição Federal, que provocam o poder judiciário no sentido deste atuar junto ao executivo. De fato, essa situação tem sido observada desde o ano de 2020 com relação às medidas de restrição para conter a pandemia de COVID-19. Enquanto o governo defende que o isolamento social, as medidas de lockdown e a obrigatoriedade do uso de máscaras ferem a liberdade individual e não define as medidas necessárias para conter o avanço da pandemia, o Supremo Tribunal Federal (STF) afirma que decretos estaduais e municipais podem ser publicados, quando o governo não apresenta essas medidas. Em vários momentos, o Presidente da República Jair Bolsonaro inverteu a responsabilidade de não definir uma política efetiva e clara de contenção da pandemia, localizando-a no STF ao afirmar, em várias ocasiões, que fora impedido pelo STF de formular tais políticas. Além disso, em dois momentos do ano de 2021 o Presidente, convicto de que isolamento social e lockdown ferem a liberdade individual, faz duras críticas ao STF. A Tabela 6, confeccionada pela pesquisa, apresenta uma amostra dessas críticas.

Tabela 6. Críticas ao STF no ano de 2021.

\begin{tabular}{|l|l|}
\hline \multicolumn{1}{|c|}{ Afirmações } & \multicolumn{1}{|c|}{ Data/Fonte } \\
\hline $\begin{array}{l}\text { Amigos do Supremo Tribunal Federal, daqui a pouco vamos ter uma crise enorme aqui. Eu vi que um } \\
\text { ministro despachou lá um processo para me julgar por genocídio. Olha, quem fechou tudo e está com } \\
\text { a política na mão não sou eu. Agora, eu não quero aqui brigar com ninguém, mas estamos na iminência } \\
\text { de ter um problema sério no Brasil. }\end{array}$ & $\begin{array}{l}\text { Fala endereçada ao STF em } \\
14 / 04 / 2021 \text { (BandNews, 2021) }\end{array}$ \\
\hline $\begin{array}{l}\text { Eu não fechei comércio, não determinei que ninguém ficasse em casa, não destruí emprego. Mas o } \\
\text { Supremo Tribunal Federal disse que prefeito e governador podiam fazer o que bem entendessem. Estão } \\
\text { fazendo. Falam tanto em Constituição, os que defendem a Constituição, e estupraram o artigo 5ª da } \\
\text { Constituição. }\end{array}$ & $\begin{array}{l}\text { Fala ap/04/2021 (BandNews, 2021) } \\
\text { earadores }\end{array}$ \\
\hline
\end{tabular}

Fonte: Autor (2021).

Além disso, uma amostra de quarenta e três declarações da presidência da república, entre os dias 27 de fevereiro de 2020 e 27 de maio de 2021, exposta na Tabela 7, oferece um panorama preciso da posição assumida pelo país diante da pandemia de COVID-19. A tensão interna entre a presidência da república e o Ministério da Saúde, governos e prefeituras é evidente a ponto de, 
no ano de 2020 termos a exoneração de dois ministros da saúde e coloca de volta a suspeita de um cálculo de convicção: produzir a imunidade de rebanho a fim de recuperar a economia.

Tabela 7. As declarações do Presidente sobre a pandemia e o programa de minimização da pandemia (fevereiro de 2020- fevereiro de 2021)

\begin{tabular}{|c|c|}
\hline Declarações de Jair Bolsonaro & Data/Fonte \\
\hline O mundo todo está sofrendo. & 27/02/2020 (GzH Política). \\
\hline Não há motivo para pânico. & 06/03/2020 (BBC) \\
\hline Está superdimensionado o poder destruidor deste vírus. & 09/03/2020 (G1) \\
\hline (...) a questão do coronavirus, que não é isso tudo que a grande mídia propala. & $10 / 03 / 2020(\mathrm{G} 1)$ \\
\hline Outras gripes mataram mais do que essa. & $11 / 03 / 2020(\mathrm{G} 1)$ \\
\hline $\begin{array}{l}\text { Esse vírus trouxe uma certa histeria e alguns governadores (...) estão tomando medidas que vão } \\
\text { prejudicar e muito a nossa economia. }\end{array}$ & 17/03/2020 (CNN. Brasil). \\
\hline Depois da facada, não vai ser uma gripezinha que vai me derrubar. & 20/03/2020 (Estadão). \\
\hline $\begin{array}{l}\text { Brevemente, o povo saberá que foi enganado por esses governadores e por parte da grande mídia } \\
\text { nessa questão do coronavirus. }\end{array}$ & 22/03/2020 (Folha de São Paulo) \\
\hline $\begin{array}{l}\text { A dose do remédio não pode ser excessiva de modo que o efeito colateral seja mais danoso que o } \\
\text { próprio vírus. }\end{array}$ & 23/03/2020 (Correio Brasiliense) \\
\hline $\begin{array}{l}\text { (...) algumas poucas autoridades, estaduais e municipais, devem abandonar o conceito de terra } \\
\text { arrasada, a proibição de transportes, o fechamento do comércio e o confinamento em massa. }\end{array}$ & 24/03/2020 (Terra) \\
\hline Outros vírus mataram bem mais do que este e não teve essa comoção toda. & $25 / 03 / 2020(\mathrm{G} 1)$ \\
\hline $\begin{array}{l}\text { O maior remédio para qualquer doença é o trabalho (...). Não podemos agir dessa maneira } \\
\text { irresponsável. (...) Vão quebrar o Brasil por conta do vírus? }\end{array}$ & 27/03/2020 (Correio Braziliense) \\
\hline tá com medinho de pegar vírus? Brincadeira. E o vírus é uma coisa que $60 \%$ vão ter, ou $70 \%$. & 02/04/2020 (CNN Brasil) \\
\hline Houve uma potencialização das consequências do vírus. Levaram o pavor para o público, histeria. & 20/04/2020 (UOL) \\
\hline (...) E daí? Lamento. Quer que eu faça o que? Eu sou Messias, mas não faço milagre. & 28/04/2020 (G1) \\
\hline Não adianta a imprensa querer botar na minha conta estas questões que não cabem a mim. & 29/04/2020 (Estadão) \\
\hline $\begin{array}{l}\text { É uma neurose. } 70 \% \text { da população vai apanhar o vírus. Não há nada que eu possa fazer. É uma } \\
\text { loucura. }\end{array}$ & 10/05/2020 (G1) \\
\hline $\begin{array}{l}\text { Estou exigindo a questão da cloroquina agora também. Se o Conselho Federal de Medicina decidiu } \\
\text { que pode usar cloroquina desde os primeiros sintomas, por que o governo federal via Ministro da } \\
\text { Saúde vai dizer que é só em caso grave? Eu sou comandante, PR, para decidir, para chegar para } \\
\text { qualquer ministro e falar o que está acontecendo. E a regra é essa, o norte é esse. }\end{array}$ & 13/05/2020 (Valor Econômico) \\
\hline Quem for de direita toma cloroquina, quem for de esquerda toma Tubaína. & 19/05/2020 (Estado de Minas) \\
\hline $\begin{array}{l}\text { Ou a OMS realmente deixa de ser uma organização política, até partidária pode-se dizer, ou nós } \\
\text { estudamos sair de lá. }\end{array}$ & 05/06/2020 (G1) \\
\hline $\begin{array}{l}\text { Lembro à Nação que, por decisão do STF, as ações de combate à pandemia (fechamento do comércio } \\
\text { e quarentena, p.ex.) ficaram sob total responsabilidade dos Governadores e dos Prefeitos. }\end{array}$ & 08/06/2020 (Twitter) \\
\hline $\begin{array}{l}\text { Estamos praticamente vencendo a pandemia. O governo fez tudo para que os efeitos negativos da } \\
\text { mesma fossem minimizados, ajudando prefeitos e governadores com necessidades na saúde. (...) } \\
\text { [Brasil] foi um dos países que menos sofreu com a pandemia. }\end{array}$ & $11 / 09 / 2020(\mathrm{NSC})$ \\
\hline $\begin{array}{l}\text { Entramos em 2020, e tivemos o problema da pandemia que, no meu entendimento, foi } \\
\text { superdimensionado. }\end{array}$ & 14/10/2020 (Valor Econômico) \\
\hline Está acabando a pandemia no Brasil. & 28/10/2020 (O Globo) \\
\hline $\begin{array}{l}\text { Tudo agora é pandemia. Tem que acabar com esse negócio, pô. Lamento os mortos, lamento. Todos } \\
\text { nós vamos morrer um dia. Não adianta fugir disso, fugir da realidade. Tem que deixar de ser um país } \\
\text { de maricas, pô. }\end{array}$ & $10 / 11 / 2020(\mathrm{G} 1)$ \\
\hline Conversinha $(\ldots)$ & 13/11/2020 (IG) \\
\hline $\begin{array}{l}\text { Parabéns a vocês que não se mostraram frouxos na hora da angústia, como diz aqui a passagem } \\
\text { bíblica. }\end{array}$ & 18/11/2020 (Jornal do Comercio) \\
\hline
\end{tabular}




\begin{abstract}
A questão da máscara, ainda vai ter um estudo sério falando sobre a efetividade da máscara... é o último tabu a cair.

Estamos vivendo um finalzinho de pandemia. (...) Não temos notícia dos nossos irmãos da África, abaixo do deserto do Saara, de grande quantidade de óbitos por Covid e todos esperavam justamente o contrário. A pessoa com alguma deficiência alimentar, pessoas mais pobres, fossem ser em boas e quantidade vitimadas. E não foi por quê? Eles tratam lá, muito, infelizmente, a malária. Então o elemento chegava com malária e com Covid-19, era tratado com hidroxicloroquina e ficava bom (...)
\end{abstract}

Lá no meio dessa bula está escrito que a empresa não se responsabiliza por qualquer efeito colateral. Isso acende uma luz amarela. A gente começa a perguntar para o povo: você vai tomar essa vacina?

Nós pousaremos logo mais em Porto Seguro, e Porto Seguro é uma cidade da Bahia que marca história também, que ali eu acabei de conversar com ela novamente, mora a doutora Raissa, uma médica, que no meu entender foi uma das pioneiras no tratamento precoce, então vamos nos encontrar, bater um papo, vai estar acompanhada de alguns médicos da região. Inclusive é uma cidade cujo prefeito, cujo governo local adotou esse procedimento, e foi muito bem-sucedido na questão política.

A pandemia, realmente, está chegando ao fim. Temos uma pequena ascensão agora, que chama de pequeno repique que pode acontecer, mas a pressa da vacina não se justifica. (...) Vão inocular algo em você. O seu sistema imunológico pode reagir, ainda de forma imprevista.

(...) tive a melhor vacina: o vírus. Sem efeito colateral.

Quem frequenta a praia, pega um sol e o sol é o que fixa a vitamina D no corpo. Tiveram problemas graves? Não. Tem a solução que está aí (...) É uma constatação de dezenas de milhares de médicos (...) outros não acreditam, tudo bem. Agora qual a alternativa? É ficar em casa e quando sentir falta de ar ir para o hospital como incentivava aqui a rede Globo com seu marqueteiro Mandetta? Você vai para o hospital fazer o que se não tem remédio? Não faz mal. Se não quiser tomar não tome, mas não fique falando besteira e tentando desestimular quem queira tomar. Não faz mal.

Por que o número de mortes está sendo menor no Brasil? Pelo tratamento precoce. Não tem outra explicação. Graças ao voluntarismo de algumas dezenas de milhares de médicos que resolveram levar avante isso. Comprovaram na ponta da linha. Trataram com hidroxicloroquina, trataram com ivermectina, com anita, com azitromicina e deu certo. (...) Não tem comprovação científica. Ô cara, mas não tem efeito colateral, sequer a questão do coração, a arritmia.

Se um médico não receitar o tratamento precoce, procure outro médico. Não tem efeito colateral. Se esperar sentir falta de ar, ir pro hospital pra ser intubado, mais ou menos $70 \%$ morrem. Vamos tomar cuidado agora.

Estudos clínicos demonstram que o tratamento precoce da Covid, com antimaláricos, podem reduzir a progressão da doença, prevenir a hospitalização e estão associados à redução da mortalidade. @alexandregarcia.

Nós estamos fazendo tudo o possível apesar do Supremo ter me proibido de fazer isso. Eu estou cometendo um crime por ajudar. (...) Há poucos meses atrás o Brasil era o país em que mais morria, agora estamos na casa do $22^{\circ}, 23^{\circ}$ lugar, o que que leva a isso, tratamento precoce, que é demonizado pelo João Dória e tantos outros. (...) Não tem nenhum remédio ainda reconhecido cientificamente, mas experimentalmente nós temos notícias da ivermectina, hidroxicloroquina, anita... e onde está se usando isso a morte ter caído vertiginosamente, e tanto é que o Brasil já não é mais o primeiro em número de mortes por milhão de habitantes.

Semana passada a temperatura subiu em Manaus e os problemas começaram a aparecer, conversei com o ministro Pazuello e ele na segunda de manhã foi para Manaus e por lá permaneceu por 3 dias, não só tomou pé da situação caótica que se encontrava ali na capital, bem como tomou providências a respeito, apesar de eu estar proibido de tomar muitas medidas no combate ao coronavírus. Enviamos pra lá cilindros, já chegou lá, levado pela força aérea um hospital de campanha, ele imediatamente adotou o tratamento precoce do Covid, que é hidroxicloroquina, que é ivermectina, que é anita, azitromicina, entre outras coisas.

Olha você aí, prefeito governador prendendo as pessoas na praia, cada vez mais a gente vê que essa política não está dando certo, tá dando certo para destruir empregos, olha o problema aqui em SP e BH, com nova decretação por parte do chefe do executivo, São Paulo por exemplo não abrir nada após as 20 e sábado e domingo, olha só vai levar ao desemprego. (...) E as pessoas que ficam em casa são responsáveis pela mortes suicídios, e a maioria dos casos de infecções acontece onde? dentro de casa. (...) O Conselho Nacional de Medicina incentiva a medicação para Covid com aquele velho chavão fora de bula, não apoia nem desapoia mas diz claramente, que médico na ponta da linha tem que ser respeitado.... Nas minhas observações aqui eu quero receitar para você o medicamento que é usado para combater a malária, não pra Covid, mas temos aqui observado que hidroxicloroquina diminui a carga viral, os efeitos colaterais são esses, não tem arritmia. (...) A
26/11/2020 (Folha de São Paulo)

10/12/2020 (O Globo)

$16 / 12 / 2020$ (Nexo Jornal)

17/12/2020 (Brasil Planalto Federal)

19/12/2020 (Correio do Povo)

23/12/2020 (Notícias UOL)

07/01/2021 (Estado de Minas)

14/01/2021 (Bolsonaro, Live)

$15 / 01 / 2021(\mathrm{R} 7)$

15/01/2021 (Bolsonaro, Twitter)

15/01/2021 (Carta Capital)

17/01/2021 (Bolsonaro, Live)

28/01/2021 (Bolsonaro, Live ) 
informação que nós temos é que mais cedo a ou mais tarde a hidroxicloroquina, ivermectina realmente não aumenta a carga viral e cura da Covid-19. E quando comprovar vocês vão ver, sabendo que das 200 mil, 140 poderiam ter sido tratadas e não serem levadas a óbito.

A questão de tratamento precoce, que ainda é muito politizada no Brasil. Temos aí, alguma coisa, alguns medicamentos que são usados pra outra coisa, que muitos médicos tem usado no tratamento precoce. E a pergunta que eu faço né: se não faz mal, por que não tomar? Agora a vacina é algo novo, tanto é que é experimental.

Eu não vou falar aquilo que eu tomei lá no Brasil se não vão me cortar o sinal da internet, mas vocês sabem o que eu tomei. (..) Eu tive os sintomas há um mês atrás mais ou menos, sintomas igualzinho o que eu tive na primeira vez que fui infectado. O que que eu fiz? Tomei aquilo e ponto final. (...) o que eu tomei, o pessoal toma aqui direto na Amazônia, sem receita médica, toma para combater o que? A malária. O cara foi acometido de malária, pega aqueles comprimidos, aquele que eu mostrei para a ema e toma para a malária.

Fonte: Henschel de Lima (2020-2021).

A amostra de declarações da presidência da república, expostas na tabela 6 , oferece um panorama preciso da posição assumida pelo país diante da pandemia de COVID-19. A tensão interna entre a presidência da república e o Ministério da Saúde, governos e prefeituras - a ponto de, no ano de 2020 termos a exoneração de dois ministros da saúde - vem impondo um custo elevado à população brasileira. A ausência de diretrizes do governo federal junto ao Ministério da Saúde para um plano científico de isolamento social e abertura gradativa para o país, para aquisição de insumos hospitalares para abastecimento dos hospitais federais, estaduais e municipais do país direcionados para o tratamento da COVID-19, de prevenção do avanço da contaminação pelo país até as populações indígenas e quilombolas (mais vulneráveis à infecção viral) teve, como reflexo, a subnotificação dos sos por todo o país e a sobrecarga de todos os níveis de atenção à saúde (em especial, o nível terciário das internações hospitalares e da medicina intensivista). De fato, o Brasil atingiu, em 21 de fevereiro de 2021, a marca de 10.139.148 de contaminados com cerca de 245.977 mortes, (de acordo com o Consórcio de Veículos de Imprensa, a partir dos dados das Secretarias Municipais de Saúde), produzindo sequelas políticas, econômicas e de saúde na população.

\subsection{O aporte financeiro para ciência, tecnologia e inovação no Brasil}

O posicionamento diante da pandemia de COVID-19, assumido pelo governo brasileiro desde a sua declaração pela OMS, é inseparável de outro fenômeno observado: os vetos presidenciais a Lei Complementar 177/2021 que estabelece que o Fundo Nacional de Ciência e Tecnologia (FNDCT), a redução do orçamento do Conselho Nacional de Desenvolvimento Científico e Tecnológico (CNPq) e da Coordenação de Aperfeiçoamento de Pessoal de Nível Superior (CAPES).

Com relação ao FNDCT, este deveria, pela Lei Complementar 177/2021, ter seus recursos protegidos de contingenciamento. Os vetos recaem sobre a disponibilidade integral dos recursos vinculados ao FNDCT, para aplicações estratégicas de longo prazo, e sem necessidade de devolver ao Tesouro Nacional. Em 2020, esse contingenciamento se verificara: o FNDCT tinha mais de R\$ 6 bilhões autorizados pelo Orçamento para aplicação em ciência, tecnologia e inovação, mas foram contingenciados, pelo governo federal, $\mathrm{R} \$ 5$ bilhões com o objetivo de atingir a meta fiscal. Ou seja, foram contingenciados cerca de $80 \%$ do FNDCT (Coalizão Ciência e Sociedade, 2021).

O orçamento do CNPq reduziu 84.4\% em 2020. E quando observamos o orçamento da Coordenação de Aperfeiçoamento de Pessoal de Nível Superior (CAPES), responsável pela política de pós-graduação no Brasil, a situação de retrocesso é extremamente preocupante e se generaliza para todas as áreas: Colégio de Ciências da Vida, Colégio de Ciências Exatas e Tecnológicas e Colégio de Humanidades (que inclui as ciências humanas, ciências sociais, linguística, letras e artes). A Figura 1 apresenta a parcela dos investimentos em bolsas em todas as áreas científicas na CAPES entre 2011 e 2021 
Figura 1. Investimentos da CAPES em bolsas de pós-graduação (2011-2021).

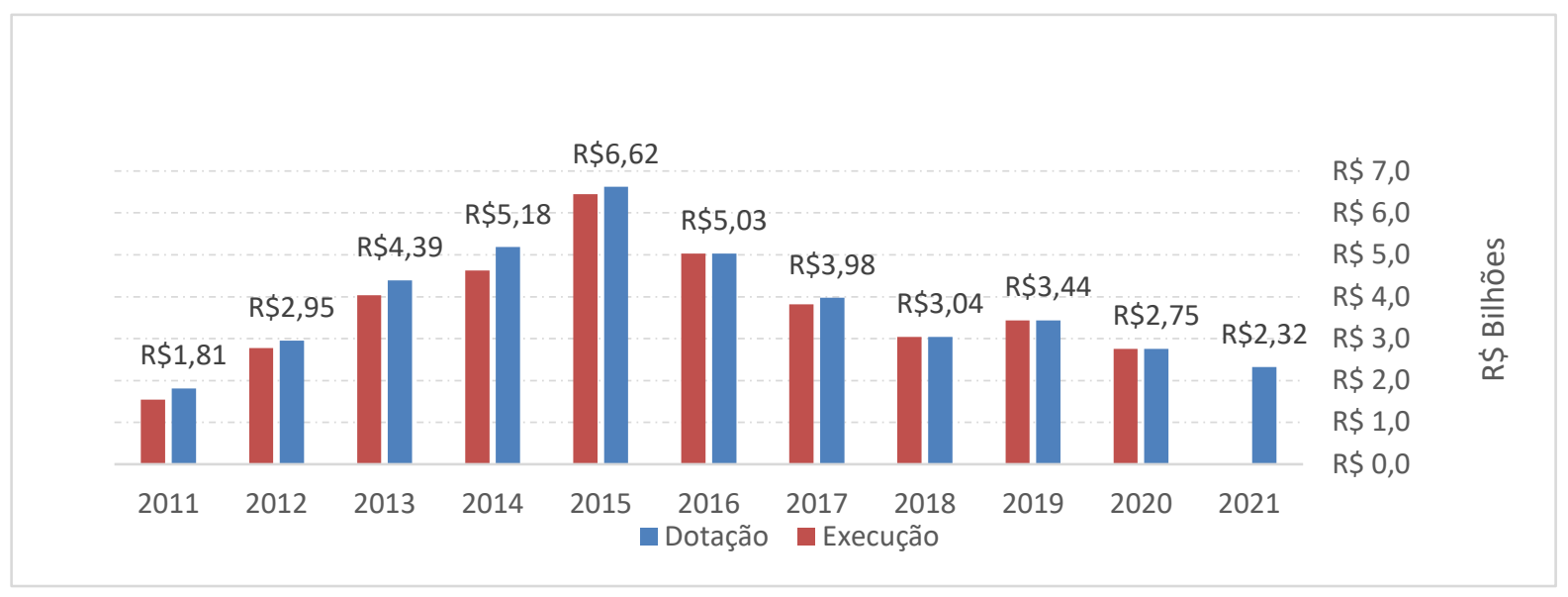

Fonte: CAPES (2021).

A Figura 1 apresenta, em azul, o total da dotação das despesas autorizadas para bolsas de pós-graduação nos últimos dez anos, em vermelho, o total desses valores executados. Não foi localizado o detalhamento da previsão e/ou execução orçamentária por áreas ou colégios de avaliação da pós-graduação nacional. No entanto, os dados permitem atestar que, em números absolutos, o orçamento da Capes regrediu em 2021 a uma condição similar ao ano de 2011, sem talvez incluir o cálculo da inflação. Se considerarmos esse cálculo, certamente teremos que concordar com a avaliação de um outro colega, o neurocientista Sidarta Ribeiro (2020) de que o orçamento da CAPES retrocedera 20 anos, ou seja, para valores similares ao ano de 2001.

Os sucessivos cortes orçamentários em Ciência e Tecnologia e no sistema de pós-graduação brasileiro, nos coloca diante da ameaça à continuidade de pesquisas já existentes e da produção de novas pesquisas no país. Conforme afirmara outro professor e neurocientista brasileiro, extremamente importante no cenário de descobertas brasileiras na área - o professor Roberto Lent, da UFRJ - o atraso científico em um laboratório e/ou grupo de pesquisa não é como uma estrada esburacada. Uma estrada tem conserto assim que o dinheiro chega; em semanas, com dinheiro, temos o início das obras de reconstrução e conserto da estrada. Um laboratório e/ou grupo de pesquisa, que sofre cortes financeiros, leva muitos anos para começar a acompanhar a velocidade das descobertas científicas, das atividades de pesquisa do mundo lá fora, e com perdas irrecuperáveis de alunos e pesquisadores brasileiros que acabam saindo do país ou desistindo da dedicação à pesquisa (Lent, 2021): “A ciência brasileira chegou à beira do colapso, pois a sua principal ferramenta de financiamento - o Fundo Nacional de Ciência e Tecnologia, FNDCT - enfrenta vetos do presidente da República que o desidratarão inevitavelmente nos tempos de escassez que se aproximam”.

\section{Conclusão: os Índices de Orientação Ideológica do Governo Brasileiro para o Enfrentamento da Pandemia}

A pesquisa exploratória e descritiva realizada, ao longo de 2020, no Laboratório de Psicopatologia Fundamental em Estudos de Subjetividade e Emergência Humanitária, para delimitar uma história psicossocial da resposta brasileira ao impacto da COVID-19 na saúde da população, obteve resultados que acabam por reforçar as expressões utilizadas pelos moradores de Wuhan, em dezembro de 2019, assim que ocorrera o desencadeamento da pandemia na região: fim do mundo e pânico em Wuhan (Tavares Lima et al, 2020).

Em primeiro lugar, essas expressões são sintomas da gravidade da emergência humanitária em que o mundo está mergulhado desde o ano de 2020, provando que a COVID-19 é mais patógena do que as infecções virais conhecidas pela ciência, até o momento e que os países efetivamente não estão preparados para o enfrentamento de pandemias - ainda que lições e diretrizes 
tenham sido elaboradas a partir do conhecimento de emergências humanitárias anteriores. O mundo também não está preparado para a carga de sofrimento psíquico decorrente da pandemia e nem a pesquisa científica sabe, ao certo, as formas clínicas assumidas pelo sofrimento psíquico e nem a sua magnitude. No entanto, esforços científicos no mundo inteiro, vem trabalhando no sentido de descobrir e produzir vacinas que previnam a infecção viral, bem como medicamentos anti-retrovirais eficazes na terapêutica. Esforços científicos, no mundo inteiro, vêm trabalhando no sentido de identificar mais precocemente, a carga de sofrimento psíquico que assolará o mundo, bem como as terapêuticas necessárias para sua estabilização.

Em segundo lugar, as expressões fim do mundo e pânico em Wuhan qualificam os resultados obtidos na pesquisa. Tanto no que se refere ao mapeamento dos fenômenos clínicos associados ao sofrimento psíquico de pacientes atingidos pela COVID-19, como no que se refere a sistematização de informações e ações dos países e do atual governo brasileiro em relação a pandemia de COVID-19, os resultados permitiram formular os dez índices de orientação ideológica do governo brasileiro para o enfrentamento da pandemia. Eles indicam elevada orientação ideológica, interferindo diretamennte na formulação de políticas públicas de saúde e segurança sanitária para sua prevenção e combate:

1.Qualificar a pandemia de COVID-19 como vírus chinês em clara atitude xenofóbica.

2.Minimizar a gravidade da infecção viral com banalização de seus sintomas e sequelas.

3.Minimizar o custo de vidas por ela imposto.

4.Minimizar a importância das políticas de saúde e segurança sanitária, baseadas em evidências científicas, para a população.

5.Interferir na publicização das informações referentes a forma de contaminação e ao número de óbitos.

6.Produzir confusão conceitual no que se refere a terapêutica médica e sua eficácia contrariando, uma vez mais, pesquisa científica baseada em evidências.

7.Ignorar a orientação científica no tocante a transmissão viral e a prevenção da contaminação.

8.Contribuir ativamente para a amplificar, na população brasileira, a reação psicológica negacionista frente a gravidade da pandemia por meio da difusão de notícias, sem base científica, relativas a eficácia da Hidroxicloroquina e Ivermectina no tratamento da COVID-19.

9. Defender a imunidade de rebanho por infecção e transmissão, ignorando as evidências sobre a elevada capacidade de mutação do vírus.

10. Reduzir o papel das agências de fomento no avanço do conhecimento científico no Brasil.

A população brasileira vem testemunhando os efeitos nocivos desta posição ideológica: a crise no fornecimento de oxigênio para os hospitais em Manaus, a circulação da variante P1 por todo o território nacional, a ausência de clareza quanto ao Cronograma Nacional de Distribuição de Vacinas e ao Plano Nacional de Imunização (PNI), sobrecarregando prefeituras e governos estaduais quanto a responsabilidade de assumir o PNI. O presente artigo conclui indicando como essa posição ideológica torna o Estado brasileiro incompetente para traçar planos e estabelecer uma estratégia no campo da saúde e segurança sanitária, consistente, para o enfrentamento da pandemia de COVID-19.

\section{Referências}

AE. (2020). A pressa da vacina não se justifica, diz Bolsonaro. Correio do Povo. https://www.correiodopovo.com.br/not\%C3\%ADcias/pol\%C3\%ADtica/a-pressada-vacina-n\%C3\%A3o-se-justifica-diz-bolsonaro-1.540858.

BandNews. (2021). Bolsonaro diz esperar "sinalização do povo" para tomar providências contra crise. Band News. https://www.band.uol.com.br/noticias/bolsonarodiz-esperar-sinalizacao-do-povo-para-tomar-providencias-contra-crise-16344767

BBC News. (2020). Não há motivo para pânico', diz Bolsonaro em pronunciamento sobre coronavírus. BBC News Brasil. https://www.bbc.com/portuguese/brasil51777889 
Benke, E. (2020). 'Não vão botar no meu colo essa conta', diz Bolsonaro sobre mortes pelo coronavírus. Estadão. https://politica.estadao.com.br/noticias/geral,naovao-botar-no-meu-colo-essa-conta-diz-bolsonaro-sobre-mortes-pelo-coronavirus,70003286981

Benke, E. (2020). 'Eu tive a melhor vacina, o vírus', diz Bolsonaro. Notícias UOL. https://noticias.uol.com.br/ultimas-noticias/agencia-estado/2020/12/23/eu-tivea-melhor-vacina-o-virus-diz-bolsonaro.htm?cmpid=copiaecola.

Bolsonaro, J. (2020). Lembro à Nação que, por decisão do STF, as ações de combate à pandemia (fechamento do comércio e quarentena, p.ex.) ficaram sob total responsabilidade dos Governadores e dos Prefeitos. Twitter. https://twitter.com/jairbolsonaro/status/1269942255298777095

Bolsonaro, J. (2021). Live da Semana 14/01/21. https://fb.watch/5VTJS1b84o/

Bolsonaro, J. (2020). Estudos clínicos demonstram que o tratamento precoce da Covid, com antimaláricos, podem reduzir a progressão da doença, prevenir a hospitalização e estão associados à redução da mortalidade. @alexandregarcia. Twitter. https://twitter.com/jairbolsonaro/status/13501499120 09334784?ref_src=twsrc\%5Etfw\%7Ctwcamp\%5Etweetembed\%7Ctwterm\%5E1350149912009334784\%7Ctwgr\%5E\%7Ctwcon\%5Es1_\&ref_url=https\%3A\%2F $\% 2$ Fwww.correiobraziliense.com.br\%2Fpolitica\%2F2021\%2F01\%2F4900732-post-de-bolsonaro-sobre-tratamento-precoce-e-marcado-como-informacaoenganosa.html

Bolsonaro, J. (2021). Live da Semana 28/01/2021. https://www.youtube.com/watch?v=SNLP3GJD-mc

Bolsonaro, J. (2021). Live da Semana 04/02/2021. https://www.youtube.com/watch?v=zW7ihlX7a24

Bolsonaro, J. (2021). Twitter. https://twitter.com/jairbolsonaro/status/1350149912009334784

Bolsonaro, J. (2021). Live 27/05/21 PEF Maturacá/AM. https://www.youtube.com/watch?v=XWYTur5g-u0

Bolsonaro, J. (2021). Entrevista ao Programa 'Pingos nos is'. Jovem Pan. https://www.youtube.com/watch?v=JSmTzQearO8

Brandão, M. (2020). Escritos na quarentena 2: Toda ciência é humana. O Público e o Privado, 36, 234-242.

Brasil. Planalto Federal. (2020). Discurso do Presidente da República, Jair Bolsonaro, na Cerimônia de Posse do senhor Gilson Machado, Ministro de Estado do Turismo - Palácio do Planalto. https://www.gov.br/planalto/pt-br/acompanhe-o-planalto/discursos/2020/discurso-do-presidente-da-republica-jair-bolsonaro-nacerimonia-de-posse-do-senhor-gilson-machado-ministro-de-estado-do-turismo-palacio-do-planalto

Brasil. Ministério da Saúde. FIOCRUZ. (2020). Saúde mental e Atenção psicossocial na Pandemia COVID-19: Recomendações Gerais. FIOCRUZ.

Briere, J., Spinazzola, J. (2005). Phenomenology and Psychological Assessment of Complex Posttraumatic States. Journal of Traumatic Stress, 18(5), 401-412.

Capes. (2021). Orçamento em Reais. https://www.gov.br/capes/pt-br/acesso-a-informacao/institucional/orcamento-evolucao-em-reais\#R.

Carta Capital (2021). Bolsonaro repete fake news de que STF o 'proibiu' de combater a Covid-19. Carta Capital. https://www.cartacapital.com.br/politica/bolsonaro-repete-fake-news-de-que-stf-o-proibiu-de-combater-a-covid-19/

Cepedisa (2021). Mapeamento e Análise das Normas Jurídicas de Resposta à COVID-19 no Brasil. Universidade de São Paulo.

CNN. Brasil (2020). Bolsonaro volta a chamar medidas contra coronavírus de histeria. CNN Brasil. https://www.cnnbrasil.com.br/politica/2020/03/17/bolsonarovolta-a-falar-em-histeria-e-diz-que-medidas-contra-coronavirus-afetam

Coalizão Ciência e Sociedade. (2021). É preciso derrubar os vetos que ameaçam nos levar a um futuro sem ciência. Direto da Ciência. http://www.diretodaciencia.com/2021/02/13/e-preciso-derrubar-os-vetos-que-ameacam-nos-levar-a-um-futuro-sem-ciencia/

Cloitre, M. et al. (2014). Distinguishing PTSD, Complex PTSD, and Borderline Personality Disorder: a latent class analysis. European Journal of Psychotraumatology, 5(25097). http://dx.doi.org/10.3402/ejpt.v5.25097

Correa, M (2020). 'Parabéns a vocês que não se mostraram frouxos', diz Bolsonaro citando Covid-19. Jornal do Comercio. https://www.jornaldocomercio.com/_conteudo/politica/2020/11/766393-parabens-a-voces-que-nao-se-mostraram-frouxos--diz-bolsonaro-citando-covid-19.html.

Correio do Povo. (2020). A pressa da vacina não se justifica, diz Bolsonaro. Correio do Povo. https://www.correiodopovo.com.br/not\%C3\%ADcias/pol\%C3\%ADtica/a-pressa-da-vacina-n\%C3\%A3o-se-justifica-diz-bolsonaro-1.540858

Cury, T. (2020). Bolsonaro volta a atacar governadores e desafia: 'Tá com medinho do vírus?' CNN Brasil. https://www.cnnbrasil.com.br/politica/2020/04/02/bolsonaro-volta-a-atacar-governadores-em-pandemia-e-desafia-ta-com-medinho

Dantas, C., Grandin, F. \& Manzano, F. (2020). Bolsonaro repete que 70\% pegarão coronavírus; cientistas estimam 1,8 milhão de mortes se isso ocorrer. G1. https://g1.globo.com/bemestar/coronavirus/noticia/2020/05/12/bolsonaro-repete-que-70percent-pegarao-coronavirus-cientistas-estimam-18-milhao-de-mortes-seisso-ocorrer.ghtml

Da Redação. (2020). Bolsonaro volta a atacar governadores: 'Povo saberá que foi enganado'. Veja. https://veja.abril.com.br/politica/bolsonaro-volta-a-atacargovernadores-povo-sabera-que-foi-enganado/

Datena, J .L. (2021). Bolsonaro chama Dória de 'moleque’. Brasil Urgente. https://youtu.be/IPvKinvRO8s.

Estado de Minas. (2020). Bolsonaro: pessoas que vão à praia não têm problemas graves com Covid-19. Estado de Minas. https://www.em.com.br/app/noticia/politica/2021/01/07/interna_politica,1227047/bolsonaro-pessoas-que-vao-a-praia-nao-tem-problemas-graves-com-covid-

19.shtml 
Estado de Minas. (2021). Bolsonaro: pessoas que vão à praia não têm problemas graves com COVID-19. Estado de Minas. https://www.em.com.br/app/noticia/politica/2021/01/07/interna_politica,1227047/bolsonaro-pessoas-que-vao-a-praia-nao-tem-problemas-graves-com-covid19.shtml

Farias, V. (2020). Em meio a alta de mortes, Bolsonaro diz que Brasil está vivendo o 'finalzinho da pandemia'. Jornal o Globo. https://oglobo.globo.com/sociedade/em-meio-alta-de-mortes-bolsonaro-diz-que-brasil-esta-vivendo-finalzinho-da-pandemia-24790590

Fernandes, A. (2020). "O maior remédio pra qualquer doença é o trabalho", diz Bolsonaro. Correio Braziliense. https://www.correiobraziliense.com.br/app/noticia/politica/2020/03/27/interna_politica,840821/o-maior-remedio-pra-qualquer-doenca-e-o-trabalho-dizbolsonaro.shtml

Folha de São Paulo (2020). Brevemente, o povo saberá que foi enganado por esses governadores e por parte da grande mídia nessa questão do coronavírus, diz Bolsonaro. Folha de São Paulo. https://www1.folha.uol.com.br/poder/2020/03/povo-sabera-que-foi-enganado-por-governadores-e-imprensa-sobre-coronavirusdiz-bolsonaro.shtml

Folha de São Paulo (2020). Uso de máscara é o último tabu a cair, diz Bolsonaro sobre prevenção da COVID. Folha de São Paulo. https://www1.folha.uol.com.br/equilibrioesaude/2020/11/mascara-e-ultimo-tabu-a-cair-diz-bolsonaro-sobre-prevencao-dacovid.shtml\#: :text=O\%20presidente\%20mencionou\%20a\%20pesquisa,tabu\%20a\%20cair\%22\%2C\%20afirmou

Frazão, F. \& Sabino, M. (2020). 'Depois da facada não vai ser uma gripezinha que vai me derrubar', diz Bolsonaro sobre Coronavirus. Estadão. https://politica.estadao.com.br/noticias/geral,depois-da-facada-nao-vai-ser-uma-gripezinha-que-vai-me-derrubar-diz-bolsonaro-sobre-coronavirus,70003241955.

Freud, S. (2020). Transitoriedade. In S. Freud, Cultura, Sociedade, Religião: O mal-estar na Cultura e Outros Escritos. Belo Horizonte: Autentica. (Trabalho original publicado em 1916).

Freud, S. (2020). Considerações Contemporâneas sobre a Guerra e a Morte. In S. Freud, Cultura, Sociedade, Religião: O mal-estar na Cultura e Outros Escritos. Belo Horizonte: Autentica. Trabalho original publicado em 1916).

Freud, S. (2020). Luto e Melancolia. In S. Freud, Cultura, Sociedade, Religião: O mal-estar na Cultura e Outros Escritos. Belo Horizonte: Autentica. Trabalho original publicado em 1917).

Freud, S. (1987). Linhas de Progresso da Técnica Psicanalítica. In S. Freud, Edição standard brasileira das obras psicológicas completas de Sigmund Freud (J. Salomão, Trad., Vol. 17, pp.). Rio de Janeiro: Imago. (Trabalho original publicado em 1918).

Freud, S. (2020). Psicologia das Massas e Análise do Eu.. In S. Freud, Cultura, Sociedade, Religião: O mal-estar na Cultura e Outros Escritos. Belo Horizonte: Autentica. Trabalho original publicado em 1921).

Freud, S. (1987). Inibição, Sintoma e Angústia. In S. Freud, Edição standard brasileira das obras psicológicas completas de Sigmund Freud (J. Salomão, Trad., Vol. 20, pp.). Rio de Janeiro: Imago. (Trabalho original publicado em 1926[1925]).

Gaglioni, C. (2020, dez 16). O sinal duplo no discurso de Bolsonaro sobre vacinação. Nexo Jornal. https://www.nexojornal.com.br/expresso/2020/12/16/O-sinalduplo-no-discurso-de-Bolsonaro-sobre-a-vacina\%C3\%A7\%C3\%A3o

Garcia, G., Gomes, P.H. \& Viana, H. (2020, abr, 28). 'E daí? Lamento. Quer que eu faça o quê?', diz Bolsonaro sobre mortes por coronavírus; 'Sou Messias, mas não faço milagre'. G1. Politica. https://g1.globo.com/politica/noticia/2020/04/28/e-dai-lamento-quer-que-eu-faca-o-que-diz-bolsonaro-sobre-mortes-por-coronavirusno-brasil.ghtml

Garcia, G. (2020). Bolsonaro aponta 'viés ideológico' na OMS e ameaça tirar Brasil da organização. G1. Política. https://g1.globo.com/politica/noticia/2020/06/05/bolsonaro-aponta-vies-ideologico-na-oms-e-ameaca-tirar-brasil-da-organizacao.ghtml

Gullino, D. (2020). Bolsonaro diz que pandemia 'está acabando' e ironiza pressa de Doria para comprar vacina. $O$ Globo. https://oglobo.globo.com/sociedade/bolsonaro-diz-que-pandemia-esta-acabando-ironiza-pressa-de-doria-para-comprar-vacina-1-24721013

Guterrez, A. (2020). ONU: serviços de saúde mental devem ser parte essencial de respostas ao coronavírus. Nações Unidas Brasil. https://nacoesunidas.org/onuservicos-de-saude-mental-devem-ser-parte-essencial-de-respostas-ao-coronavirus/.

GzH Política. (2020). Bolsonaro culpa coronavírus por alta do dólar: "O mundo todo está sofrendo". Gaúcha ZH. https://gauchazh.clicrbs.com.br/politica/noticia/2020/02/bolsonaro-culpa-coronavirus-por-alta-do-dolar-o-mundo-todo-esta-sofrendo-ck75mobaq02z301lbfyri6z47.html

G1. (2020). Bolsonaro diz que 'poder destruidor' do coronavírus 'está sendo superdimensionado'. G1. Globo. https://g1.globo.com/bemestar/coronavirus/noticia/2020/03/09/bolsonaro-diz-que-poder-destruidor-do-coronavirus-esta-sendo-superdimensionado.ghtml

G1. (2020). Bolsonaro diz que 'pequena crise' do coronavírus é 'mais fantasia' e não 'isso tudo' que mídia propaga. G1. Globo. https://g1.globo.com/politica/noticia/2020/03/10/bolsonaro-diz-que-questao-do-coronavirus-e-muito-mais-fantasia.ghtml

G1. (2020). Outros vírus mataram bem mais do que este e não teve essa comoção toda. G1. Globo. https://g1.globo.com/jornalnacional/noticia/2020/03/25/bolsonaro-volta-a-criticar-isolamento-social-para-combater-expansao-do-coronavirus.ghtml

G1, O Globo, Extra, Estadão, Folha e UOL. (2020, jun 8) Veículos de comunicação formam parceria para dar transparência a dados de Covid-19. G1. https://g1.globo.com/politica/noticia/2020/06/08/veiculos-de-comunicacao-formam-parceria-para-dar-transparencia-a-dados-de-covid-19.ghtml

Gomes, P. H. (2020). Brasil tem de deixar de ser 'país de maricas' e enfrentar pandemia 'de peito aberto', diz Bolsonaro. G1. Globo. https://g1.globo.com/politica/noticia/2020/11/10/bolsonaro-diz-que-brasil-tem-de-deixar-de-ser-pais-de-maricas-e-enfrentar-pandemia-de-peito-aberto.ghtml.

Henschel de Lima, C. (2020). Psychoanalytical Investigation of Clinical Phenomena in Psychosis, in the Pandemic Context of COVID-19. Psychology, 11(12), 


\section{7-1853. 10.4236/psych.2020.1112116}

Ig. Saúde. (2020). Em meio a aumento de casos, Bolsonaro chama segunda onda de 'conversinha'. IG. https://saude.ig.com.br/coronavirus/2020-11-13/em-meio-aaumento-de-casos-bolsonaro-chama-segunda-onda-de-conversinha.html

Klein, C. (2020). Bolsonaro volta a minimizar pandemia e diz que ela foi 'superdimensionada'. Valor Econômico. https://valorinveste.globo.com/mercados/brasile-politica/noticia/2020/10/14/bolsonaro-volta-a-minimizar-pandemia-e-diz-que-ela-foi-superdimensionada.ghtml

Lent. R. (2021). A Ciência à beira do abismo. Jornal O Globo. https://blogs.oglobo.globo.com/a-hora-da-ciencia/post/ciencia-brasileira-esta-beira-do-abismo-maso-congresso-pode-salva-la.html

Maia, G. (2020). Bolsonaro volta a minimizar coronavírus: 'outras gripes mataram mais do que essa. Jornal O Globo. https://oglobo.globo.com/economia/bolsonarovolta-minimizar-coronavirus-outras-gripes-mataram-mais-do-que-essa-24299297.

Murakawa, B. (2020). Bolsonaro 'exige' que ministro da Saúde recomende a cloroquina. Valor Econômico. https://valor.globo.com/politica/noticia/202 0/05/14/bolsonaro-exige-que-ministro-da-sade-recomende-a-cloroquina.ghtml

NSC. Brasil. (2020). Perto de 130 mil mortes, Bolsonaro diz que Brasil foi um dos que "menos sofreu" com pandemia. NSC. Saúde Bem- Estar. https://www.nsctotal.com.br/noticias/perto-de-130-mil-mortes-bolsonaro-diz-que-brasil-foi-um-dos-que-menos-sofreu-com-pandemia

Nuzzo, J. (2021). To Stop a Pandemic. A Better Approach to Global Health Security. Foreign Affairs, 36-42.

Organização Mundial da Saúde. (2015). Guia de Intervenção Humanitária (GIH-mhGAP):Manejo Clínico de Condições Mentais, Neurológicas e por Uso de Substâncias em Emergências Humanitárias. Organização Mundial da Saúde.

Organización Panamericana de la Salud. Organización Mundial de la Salud. (2018). La carga de los trastornos mentales en la Región de las Américas. Washington DC.

Ribeiro, S. (2020) Tempos da peste - Ciência em Krakatoa. Revista Piauí, 163. https://piaui.folha.uol.com.br/materia/ciencia-em-krakatoa/

Ripoll S. \& Wilkinson A. (2019). Social Science in Epidemics: Influenza and SARS Lessons Learned, SSHAP Lessons Learned Issue 3. UNICEF, IDS \& Anthrologica.

R7. (2021). Bolsonaro diz que governo fez a sua parte na crise em Manaus. Jornal R7. https://noticias.r7.com/brasil/bolsonaro-diz-que-governo-fez-a-sua-parte-na-criseem-manaus-15012021

Schmid et al. (2013). Developmental trauma disorder: pros and cons of including formal criteria in the psychiatric diagnostic systems. BMC Psychiatry, 13:3.

Soares, I. (2020). 'Pânico é uma doença mais grave que o próprio vírus', diz Bolsonaro. Correio Braziliense. https://www.correiobraziliense.com.br /app/noticia/politica/2020/03/23/interna_politica,836095/panico-e-uma-doenca-mais-grave-que-o-proprio-virus-diz-bolsonaro.shtml

Soares, I. (2020). Bolsonaro: 'Quem for de direita toma cloroquina, de esquerda toma Tubaína'. Estado de Minas. https://www.em.com.br/app/noticia/politica/2020/05/19/interna_politica,1148877/bolsonaro-quem-for-de-direita-toma-cloroquina-de-esquerda-toma-tuba.shtml.

Taste, M. (2020). Social Science in Time of Social Distancing. London School of Economics and Political Science. https://blogs.lse.ac.uk/impactofsocialsciences/2020/03/23/editorial-social-science-in-a-time-of-social-distancing/ .

Tavares lima et al. (2020). Letter to Editor - The emotional impact of Coronavirus 2019-nCoV (new Coronavirus disease). Psychiatry Research, 287. https://doi.org/10.1016/j.psychres.2020.112915

Terra (2020). Em rede nacional, Bolsonaro critica fechamento de escolas e comércio e compara coronavírus a 'resfriadinho'. Terra. https://www.terra.com.br/noticias/brasil/em-rede-nacional-bolsonaro-critica-fechamento-de-escolas-e-comercio-e-compara-coronavirus-aresfriadinho,b1af2f77608a6f2ee3d5dfb65dc491203xspjxc0.html

Thackur, V. \& Jain, A. (2020). COVID 2019-suicides: A global psychological pandemic. Brain, Behavior, and Immunity. Pre-print. https://doi.org/10.1016/j.bbi.2020.04.062

Vannuchi, R. (2020). A pandemia de Covid-19 segundo Bolsonaro: da "gripezinha" ao "e daí?". UOL. https://noticias.uol.com.br/colunas/camilovannuchi/2020/04/30/a-pandemia-de-covid-19-segundo-bolsonaro-da-gripezinha-ao-e-dai.htm 